\title{
Final height in girls with Turner's syndrome treated with once or twice daily growth hormone injections
}

Th C J Sas, S M P F de Muinck Keizer-Schrama, Th Stijnen, A van Teunenbroek, A C S Hokken-Koelega, J J J Waelkens, G G Massa, Th Vulsma, W J Gerver, H M Reeser, H E Delemarre-van de Waal, M Jansen, S L S Drop, and the Dutch Advisory Group on Growth Hormone

Department of Paediatrics, Division of Endocrinology, Sophia Children's Hospital, Dr. Molewaterplein 60, 3015 GJ Rotterdam, Netherlands Th C J Sas

S M P F de Muinck Keizer-Schrama A van Teunenbroek A C S Hokken-Koelega S L S Drop

Department of Biostatistics, Erasmus University Rotterdam, Netherlands

Th Stijnen

Catharina Hospital, Eindhoven,

Netherlands

J J J Waelkens

Leiden University Medical Centre, Leiden, Netherlands G G Massa

Emma Children's Hospital, Academic Medical Centre, Amsterdam, Netherlands Th Vulsma

Academic Hospital, Maastricht,

Netherlands

W J Gerver

Juliana Children's Hospital, The Hague, Netherlands

H M Reeser

Free University Hospital, Amsterdam, Netherlands

H E Delemarre-van de Waal

Wilhelmina Children's Hospital, Utrecht, Netherlands

M Jansen

Correspondence to: Dr Sas.

Accepted 10 August 1998

\section{Abstract}

Objectives-To study final height in girls with Turner's syndrome treated with once or twice daily injections of growth hormone (GH) in combination with low dose ethinyl oestradiol.

Design-Until final height was reached, the effect of fractionated subcutaneous injections given twice daily was compared with once daily injections of a total GH dose of $6 \mathrm{IU} / \mathrm{m}^{2} /$ day. Twice daily injections were given as one third in the morning and two thirds at bedtime. All girls concurrently received low dose oestradiol $(0.05 \mu \mathrm{g}$ ethinyl oestradiol/kg/day, increased to $0.10 \mu \mathrm{g} / \mathrm{kg} / \mathrm{day}$ after 2.25 years). Patients-Nineteen girls with Turner's syndrome aged $\geqslant 11$ years (mean (SD) 13.6 (1.7) years).

Measurements-To determine final height gain, we assessed the difference between the attained final height and the final height predictions at the start of treatment. These final height predictions were calculated using the Bayley-Pinneau (BP) prediction method, the modified projected adult height (mPAH), the modified index of potential height $\left(\mathrm{mIPH}_{\mathrm{Rus}}\right)$, and the Turner's specific prediction method (PTS RUS $_{\text {). }}$

Results-The gain in final height (mean (SD)) was not significantly different between the once daily and the twice daily regimens $(7.6(2.3) \quad v 5.1(3.2) \mathrm{cm})$. All girls exceeded their adult height prediction (range, $1.6-12.3 \mathrm{~cm}$ ). Thirteen of the 19 girls had a final height gain $>5.0 \mathrm{~cm}$. Mean (SD) attained final height was $\mathbf{1 5 5 . 5}$ (5.4) cm. A "younger bone age" at baseline and a higher increase in height standard deviation score for chronological age (Dutch-Swedish-Danish references) in the first year of GH treatment predicted a higher final height gain after GH treatment.

Conclusions-Division of the total daily GH dose (6 IU $/ \mathrm{m}^{2} /$ day) into two thirds in the evening and one third in the morning is not advantageous over the once daily GH regimen with respect to final height gain. Treatment with a GH dose of $6 \mathrm{IU} / \mathrm{m}^{2} /$ day in combination with low dose oestrogens can result in a significant increase in adult height in girls with Turn- er's syndrome, even if they start GH treatment at a relatively late age.

(Arch Dis Child 1999;80:36-41)

Keywords: Turner's syndrome; growth hormone treatment; final height; growth

Growth failure and subsequently short adult stature is one of the main features in Turner's syndrome. ${ }^{12}$ It has been shown that short stature, independent of aetiology, can be associated with psychosocial problems. ${ }^{3}$ Growth hormone $(\mathrm{GH})$ treatment improves height velocity and adult height in most girls with Turner's syndrome. ${ }^{4-12}$ Studies in patients with Turner's syndrome have shown that the initial growth response to GH treatment is dependent on the dose and frequency of administration..$^{4-61314} \mathrm{To}$ improve the growth response, intramuscular injections three times a week have been replaced by a once daily subcutaneous regimen. ${ }^{13}{ }^{14}$ However, just as in normal growing girls, ${ }^{15}$ spontaneous GH secretion in Turner's syndrome is characterised by a large peak soon after falling asleep and the occurrence of several other peaks during the course of a 24 hour period. ${ }^{16-21}$ Thus, a more frequent injection regimen might improve the growth response, as has also been suggested by a study in $\mathrm{GH}$ deficient patients. ${ }^{22}$

In this study, an attempt was made to mimic the normal pulsatile $\mathrm{GH}$ secretion pattern more closely. The total $\mathrm{GH}$ dose of $6 \mathrm{IU} / \mathrm{m}^{2}$ body surface/day was divided into two thirds in the evening and one third in the morning in one group of patients. The other group received the same total GH dose once daily, in the evening. A total dose of $6 \mathrm{IU} / \mathrm{m}^{2} /$ day was chosen instead of the more commonly used $4 \mathrm{IU} / \mathrm{m}^{2} /$ day because an earlier study has shown that on the latter dose the growth response in a somewhat older subgroup of girls with Turner's syndrome was poorer than in younger girls. ${ }^{14}$ Two year results were described earlier by our group. ${ }^{23}$ We now report follow up until final height comparing the effects of twice daily and once daily GH administration in 19 girls with Turner's syndrome aged 11 years or over concurrently receiving low dose ethinyl oestradiol.

\section{Patients and methods}

STUDY GROUP

We studied 19 previously untreated girls with Turner's syndrome, confirmed by lymphocyte 
chromosomal analysis. Before treatment, 10 girls were enrolled in a 10 week (crossover design) 24 hour GH profile study, as described earlier. ${ }^{24}$ In brief, they started taking ethinyl oestradiol $(0.05 \mu \mathrm{g} / \mathrm{kg} /$ day $)$ four weeks before they were divided randomly into the once daily or twice daily $\mathrm{GH}$ injection groups. $\mathrm{GH}$ was then administered for two weeks. Following a washout interval of two weeks, $\mathrm{GH}$ treatment was resumed for another period of two weeks, using the alternative injection frequency. The additional nine girls followed the same schedule without 24 hour GH profile testing. After a second randomisation, which was carried out independently from the first randomisation, all 19 girls entered the present study immediately after completion of the 10 week design. At the start of the crossover study, all girls had Tanner puberty stage $\mathrm{B} 1,{ }^{25}$ were aged 11 years or over, and had a Tanner and Whitehouse RUS (radius, ulna, short bones) bone age (RUS $\mathrm{BA})^{26}$ of less than 13.5 years. Exclusion criteria were: associated endocrine and/or metabolic disorders, growth failure caused by other disorders or emotional deprivation, hydrocephalus, and previous use of drugs that might interfere with $\mathrm{GH}$ treatment. Written informed consent was obtained from the girls and their parents. The study protocol was approved by the ethics committee of each participating centre.

\section{STUDY DESIGN}

After stratification for RUS BA and height standard deviation score for chronological age $\left(\right.$ HSDS $\left._{\mathrm{CA}}\right)$, the girls were divided randomly into two $\mathrm{GH}$ injection frequency groups. One group $(\mathrm{n}=9)$ received $6 \mathrm{IU} / \mathrm{m}^{2}$ body surface once daily, in the evening. A second group $(n=10)$ received the same total $\mathrm{GH}$ dose divided into one third in the morning and two thirds at bedtime. $\mathrm{GH}$ (r-hGH Norditropin; Novo Nordisk A/S, Bagsvaerd, Denmark) was injected by a pen injection system (Nordiject 24; Novo Nodisk A/S). Compliance was carefully monitored. GH treatment was stopped when height velocity had decreased to $<1 \mathrm{~cm} / \mathrm{six}$ months. The figure for final height was recorded six months after the end of treatment. From the start of the 10 week crossover study, all girls received $0.05 \mu \mathrm{g}$ ethinyl oestradiol $/ \mathrm{kg} /$ day, once daily. After the first 2.25 years of $\mathrm{GH}$ treatment, the dose of ethinyl oestradiol was increased to $0.10 \mu \mathrm{g} / \mathrm{kg} /$ day and cyclic progestagen treatment was added.

\section{GROWTH EVALUATION}

Height $(\mathrm{H})$ was measured at baseline and three monthly until final height was reached. Heights were determined according to Cameron, ${ }^{27}$ using a Harpenden stadiometer; four measurements were made on each visit by two trained observers (AvT and later ThS). Height was expressed as $\mathrm{HSDS}_{\mathrm{CA}}$ using the Roede en van Wieringen references for healthy Dutch girls $\left(\mathrm{HSDS}_{\mathrm{CA}}(\mathrm{RvW})\right)^{28}$ and the Dutch-SwedishDanish Turner's references (HSDS $\left.{ }_{\mathrm{CA}}(\mathrm{DSD})\right){ }^{2}$ At final height, $\mathrm{HSDS}_{\mathrm{CA}}$ (DSD) was calculated by using the mean height $(146.95 \mathrm{~cm})$ and the standard deviation $(6.37 \mathrm{~cm})$ of untreated girls with Turner's syndrome (DSD references) of 21 years of age. Target height $(\mathrm{TH})$ was adapted from Dutch reference data ${ }^{28}$ with the addition of $3 \mathrm{~cm}$ for secular trend: $\mathrm{TH}=1 / 2^{\star}$ $\left(\mathrm{H}_{\text {mother }}+\mathrm{H}_{\text {father }}-12 \mathrm{~cm}\right)+3 \mathrm{~cm}$. Pubertal stages were assessed according to Tanner. ${ }^{25}$ Bone age was determined by the same two investigators (AvT and later ThS) according to Tanner and Whitehouse RUS $\mathrm{BA}^{26}$ and to Greulich and Pyle (GP BA). ${ }^{29}$ To determine final height gain, we assessed the difference between the attained final height and the final height predictions at start of treatment. These final height predictions were calculated by using the Bayley-Pinneau (BP) prediction method, ${ }^{30}$ the modified projected adult height (mPAH) ${ }^{31}{ }^{32}$ the modified index of potential height $\left(\mathrm{mIPH}_{\mathrm{RUS}}\right){ }^{32}{ }^{33}$ and the recently developed Turner's specific prediction method $\left(\mathrm{PTS}_{\mathrm{RUS}}\right)$, based on regression coefficients for height, chronological age, and RUS BA. ${ }^{32}$ The latter three methods are based on Dutch Turner's references, as described previously. ${ }^{32}$

Before any treatment, all girls underwent a $\mathrm{GH}$ provocation test by infusion of arginine $(0.5 \mathrm{~g} / \mathrm{kg}$ body weight in 30 minutes). In addition, blood was taken for the determination of insulin-like growth factor I (IGF-I), IGF binding protein 3 (IGFBP-3), and $\mathrm{GH}$ binding protein (GHBP) at the start of our study (pretreatment) and at six and 18 months after it started. The methods and the results of these measurements were described previously. ${ }^{23} 24$ 34-37

\section{STATISTICS}

Results are expressed as mean (SD) unless indicated otherwise. The Student's $t$ test or the $\chi^{2}$ test were used to test differences between groups. Student's paired sample test was used for comparing means within groups. Correlations were tested with Pearson's linear correlation coefficient. To compare final height between the once daily and twice daily groups, a multiple linear regression analysis adjusted for baseline variables was performed. For this analysis, RUS BA and the average of the four final height predictions were chosen as baseline variables. In the search for determinants of treatment success (final height gain $=$ attained final height minus predicted final height), multiple linear regression analyses, adjusted for treatment group, were done. For each possible predictive factor, separate analyses were performed. Possible predictive factors for final height gain after $\mathrm{GH}$ treatment were at baseline: chronological age, RUS BA, HSDS ${ }_{\mathrm{CA}}$ (DSD), target height, concentrations of IGF-I, IGFBP-3, IGF-I to IGFBP-3 ratio, GHBP, and the maximal $\mathrm{GH}$ value during a provocation test; after the first six months of GH treatment: the change from baseline of IGF-I, IGFBP-3, IGF-I to IGFBP-3 ratio and GHBP levels; and in the first year of $\mathrm{GH}$ treatment: the change in $\mathrm{HSDS}_{\mathrm{CA}}$ (DSD). A p value $<0.05$ was considered significant. 
Table 1 Pretreatment clinical data

\begin{tabular}{lll}
\hline & Once daily group $(n=9)$ & Twice daily group $(n=10)$ \\
\hline CA (years) & $13.3(1.7)$ & $13.8(1.8)$ \\
RUS BA (years) & $12.2(1.0)$ & $12.7(0.9)$ \\
GP BA (years) & $11.4(0.6)$ & $11.8(0.8)$ \\
Height (cm) & $134.3(5.1)$ & $140.8(7.9)$ \\
HSDS $_{\mathrm{CA}}$ (RvW) & $-3.7(1.3)$ & $-3.1(1.2)$ \\
HSDS $_{\mathrm{CA}}$ (DSD) & $0.2(1.1)$ & $1.1(1.3)$ \\
Target height (cm) & $166.5(4.5)$ & $168.3(6.3)$ \\
Karyotype & 6 & 8 \\
$\quad$ 45,X & 6 & 2 \\
$\quad$ Other & 3 & \\
\hline
\end{tabular}

Results are mean (SD).

CA, chronological age; BA, bone age, RUS, radius, ulna, short bones; GP Greulich and Pyle; $\mathrm{HSDS}_{\mathrm{CA}}$, height standard deviation score for chronological age; RvW, Roede van Wieringen references for healthy Dutch girls; DSD, Dutch-Swedish-Danish references for girls with Turner's syndrome.

Table 2 Predictions of adult height at start of growth hormone treatment

\begin{tabular}{|c|c|c|}
\hline Prediction method & $\begin{array}{l}\text { Once daily } \\
\text { group }(n=9)\end{array}$ & $\begin{array}{l}\text { Twice daily } \\
\text { group }(n=10)\end{array}$ \\
\hline Modified projected adult height & $146.7(6.0)$ & $151.5(6.9)$ \\
\hline Modified index of potential height, including RUS bone age & $146.9(3.7)$ & $151.2(5.6)$ \\
\hline Bayley and Pinneau prediction of adult height & $145.8(5.2)$ & $151.5(6.9)$ \\
\hline $\begin{array}{l}\text { Turner's specific } \mathrm{FH} \text { prediction method, including RUS bone } \\
\text { age }\end{array}$ & $147.4(5.7)$ & $151.4(6.4)$ \\
\hline Average of the four predictions & $146.7(4.9)$ & $151.4(6.3)$ \\
\hline
\end{tabular}

Results are mean (SD) centimetres.

FH, Final height; RUS, radius, ulna, short bones.

\section{Results}

GROWTH EVALUATION

Table 1 lists the baseline (after the second randomisation) clinical data of the girls. As described in a previous paper, ${ }^{23}$ at baseline, there were no relevant differences between the two groups for any of the variables. Before treatment, the mean chronological age, bone age, and $\mathrm{HSDS}_{\mathrm{CA}}$ values of the girls in the twice daily group were slightly (not significantly) higher compared with those in the once daily group.

Table 2 shows the mean predicted adult height according to the four different prediction methods. For both groups the differences between the four predictions were small and not significantly different from zero. Therefore, we used for further analyses the average of the four predictions as the predicted adult height.

Table 3 shows the clinical data at final height. The difference in final height between the two treatment groups was $2.2 \mathrm{~cm}$ in favour of the twice daily group, but this difference was not significant. However, after adjustment for baseline variables (RUS BA and the predicted adult height), the mean final height of the twice daily group minus the mean final height of the once daily group was $-1.2 \mathrm{~cm}$ (95\% confidence interval, -3.8 to 1.4 ). Thus, the once daily group had a slightly better growth response on $\mathrm{GH}$ treatment until final height compared with the twice daily group, but this difference was not significant. For both treatment groups, final height was significantly higher than the predicted adult height at start $(p \leqslant 0.001)$. Sixteen of the 19 girls have reached a final height $>150 \mathrm{~cm}$, and five of them even had a final height $>160 \mathrm{~cm}$.

The duration of GH treatment (from start of GH treatment until height velocity $<1 \mathrm{~cm} /$ six months) was significantly shorter in the twice daily group compared with the once daily group, even after adjustment for RUS BA at baseline $(p<0.02)$. No significant difference in bone maturation from the start of GH treatment until final height was found between the once daily and twice daily groups: bone age to chronological age ratio (year:year) was $0.7 v$ 0.8 , respectively.

At final height, HSDS (RvW) and HSDS (DSD) were significantly increased compared with baseline in the once daily group $(p<0.001)$. In the twice daily group, both HSDS (RvW) and HSDS (DSD) were increased compared with baseline, but only the increase in HSDS (RvW) was significant $(\mathrm{p}<0.001)$. The increase in $\mathrm{HSDS}_{\mathrm{CA}}(\mathrm{RvW}$ and DSD) was higher in the once daily group compared with the twice daily group, but this difference was not significant. All girls exceeded their adult height prediction (final height gain range, $1.6-12.3 \mathrm{~cm}$ ). Thirteen of the 19 girls had a final height gain $>5.0 \mathrm{~cm}$.

\section{RELATIONS WITH GROWTH RESPONSE}

Multiple linear regression analyses of the final height gain after adjustment for treatment group revealed a significant negative correlation with baseline RUS BA $(\beta=-1.6$; $\mathrm{p}=0.021$ ) (fig 1) and a significant positive correlation with increase in $\mathrm{HSDS}_{\mathrm{CA}}$ (DSD) in the first year of $\mathrm{GH}$ treatment $(\beta=7.8$; $\mathrm{p}=<0.0001$ ) (fig 2). Final height gain was not significantly related to pretreatment chronological age, $\mathrm{HSDS}_{\mathrm{CA}}$ (DSD), target height, plasma IGF-I, IGFBP3, IGF-I to IGFBP3 ratio, GHBP, or maximum $\mathrm{GH}$ levels after provocation, nor to the change after six months of GH treatment in plasma IGF-I, IGFBP3, IGF-I to IGFBP3 ratio, and GHBP.

\section{Pubertal development}

Tanner breast stage development was not significantly different between the once daily and twice daily groups: at the end of $\mathrm{GH}$ treatment, the distribution of the number of girls with Tanner stages B1 to B5 was 1, 0, 3, 3, 2 and $0,2,2,4,2$, respectively. At the end of $\mathrm{GH}$ treatment, six girls had experienced their menarche.

Table 3 Clinical data at final height

\begin{tabular}{llllllll}
\hline $\begin{array}{l}\text { Treatment } \\
\text { group }\end{array}$ & $n$ & $\begin{array}{l}\text { Final height } \\
(\mathrm{cm})\end{array}$ & $\begin{array}{l}\text { Predicted adult } \\
\text { height }(\mathrm{cm})\end{array}$ & $\begin{array}{l}\text { Months of } G H \\
\text { treatment }\end{array}$ & $\begin{array}{l}\text { Increase HSDS } \\
\text { (RvW) }\end{array}$ & $\begin{array}{l}\text { Increase HSDS } \\
\text { (DSD) }\end{array}$ & $\begin{array}{l}\text { Final height } \\
\text { gain }(\mathrm{cm}) *\end{array}$ \\
\hline Once daily & 9 & $154.3(5.2)$ & $146.7(4.9)$ & $48.0(6.7)$ & $1.5(0.6)$ & $1.0(0.5)$ & $7.6(2.3)$ \\
Twice daily & 10 & $156.5(5.6)$ & $151.4(6.3)$ & $38.4(8.1)$ & $1.2(0.6)$ & $0.4(0.7)$ & $5.1(3.2)$ \\
Total & 19 & $155.5(5.4)$ & $149.2(6.0)$ & $42.9(8.8)$ & $1.3(0.6)$ & $0.8(0.7)$ & $6.3(3.0)$ \\
\hline
\end{tabular}

Results are mean (SD).

*Final height minus predicted adult height.

HSDS $_{\mathrm{CA}}$, height standard deviation score for chronological age; RvW, Roede van Wieringen references for healthy Dutch girls, DSD: Dutch-Swedish-Danish references for girls with Turner's syndrome. 


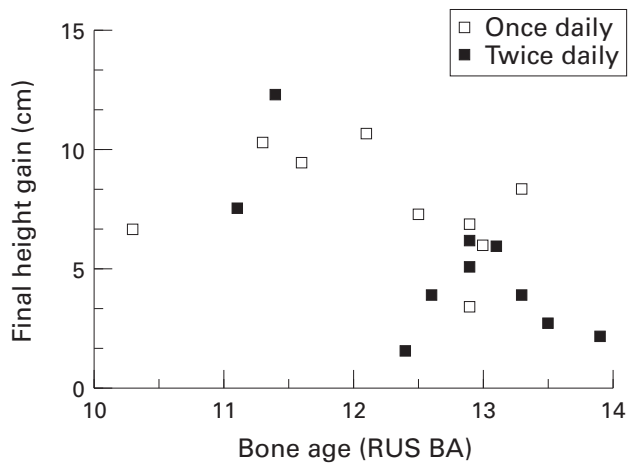

Figure 1 Relation between the final height gain (cm) and the bone age (RUS BA) (years) at start of the $G H$ treatment $(\beta=-1.6 ; p=0.021)$.

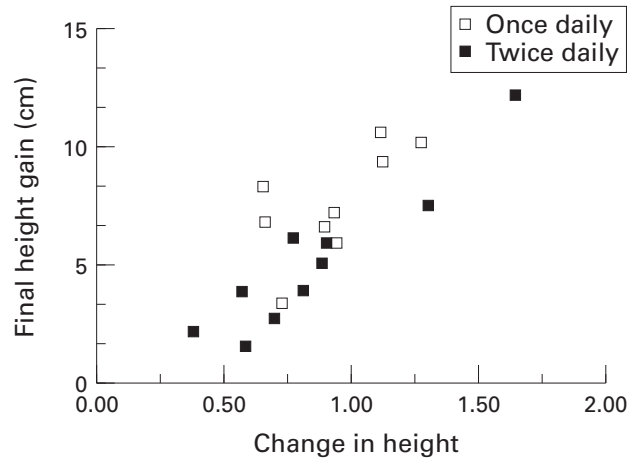

Figure 2 Relation between the final height gain $(\mathrm{cm})$ and the increase in $H S D S_{C A}$ (DSD) in the first year of $G H$ treatment $(\beta=7.8 ; p \stackrel{<=0.0001)}{=}$

SIDE EFFECTS

No clinically relevant side effects attributable to $\mathrm{GH}$ were noted.

\section{Discussion}

Division of the total daily $\mathrm{GH}$ dose $\left(6 \mathrm{IU} / \mathrm{m}^{2} /\right.$ day) into two thirds in the evening and one third in the morning is not advantageous over the once daily $\mathrm{GH}$ regimen with respect to final height gain. Final height tended towards a higher mean value with once daily $\mathrm{GH}$ compared with twice daily $\mathrm{GH}$ after correction for baseline variables, but a significant difference between the two groups was not found. The mean corrected difference in final height (twice daily minus once daily) was $-1.2 \mathrm{~cm}$ with a $95 \%$ confidence interval between -3.8 and $+1.4 \mathrm{~cm}$ in favour of the once daily group. The absence of a significant difference in final height between the once daily and twice daily groups might be caused by lack of power as a result of the relatively small numbers of girls in both groups. However, we have proved that the effect of $\mathrm{GH}$ treatment of more than $1.4 \mathrm{~cm}$ in favour of the twice daily group can be excluded with $95 \%$ confidence.

Our final height data are in line with the two year results. ${ }^{23}$ The growth response after two years' $\mathrm{GH}$ on a total daily dose of $6 \mathrm{IU} / \mathrm{m}^{2}$ in combination with $0.05 \mu \mathrm{g}$ ethinyl oestradiol $/ \mathrm{kg} /$ day was not significantly different between the two $\mathrm{GH}$ injection regimens. However, height velocity in the second year of the study and the change in $\mathrm{HSDS}_{\mathrm{CA}}$ during the second year and after two years of study was higher in the once daily group compared with the twice daily group. Thus, a tendency in favour of once daily injections was already seen in the first two years of treatment.

The 24 hour GH profiles in 10 of these girls showed that the mean area under the curve (AUC) was 3.1 times higher for the night time period compared with the day time period in the girls receiving twice daily $\mathrm{GH}$ treatment, although the $\mathrm{GH}$ dose at bedtime was only twice as high as the morning dose. In addition, the mean AUC values for the night time period were 1.9 times higher for the once daily treatment than the twice daily one, while the $\mathrm{GH}$ dose at bedtime was only 1.5 times higher in the once daily group. ${ }^{24}$ These results suggest a difference in $\mathrm{GH}$ bioavailability and are in line with the trend towards a better final height gain in the once daily group.

To our knowledge, our study is the only one in which girls with Turner's syndrome have received twice daily injections of $\mathrm{GH}$ until final height. In a study in girls with Turner's syndrome, comparing a once daily regimen with a twice daily regimen in which an equal division of a daily $\mathrm{GH}$ dose $\left(25 \mathrm{IU} / \mathrm{m}^{2} /\right.$ week $)$ was made, the change in height velocity in the first year of treatment was somewhat higher in the once daily group (mean (SD), $3.5(1.3) \mathrm{cm} /$ year) compared with the twice daily group (mean (SD), 2.7 (1.8) cm/year), but also in this study the difference was not significant. ${ }^{38}$

Apart from the small and non-significant difference in final height gain between the two groups, the duration of the $\mathrm{GH}$ treatment in our study was significantly longer in the once daily group than in the twice daily group, even after adjustment for bone age at baseline. Apart from the possibility that these differences are the result of a type I error, one can speculate that the effect of the twice daily $\mathrm{GH}$ regimen is comparable with the effect of a lower GH dose (for example, as a result of lower GH bioavailability). As a result, this causes a worse growth response than the once daily $\mathrm{GH}$ regimen. Consequently, this might cause an earlier decrease in height velocity, resulting in an earlier discontinuation of $\mathrm{GH}$ treatment, and a lower final height gain. Another explanation might be a more pronounced effect of the twice daily regimen on bone maturation than on height velocity compared with the once daily regimen. However, no significant difference in bone maturation between the two groups was found.

The final height gain was, independent of treatment group, negatively related with baseline RUS BA. Therefore, the large interindividual differences in final height gain could partly be explained by the interindividual difference in RUS BA at baseline. From a statistical point of view, it is important to mention that baseline RUS BA was only moderately and not significantly correlated $(r=0.26$; $\mathrm{p}=0.278$ ) with the adult height prediction at the start. Accordingly, this relation with final height gain cannot be explained by regression to the mean. In addition, final height gain was positively related with the increase in $\mathrm{HSDS}_{\mathrm{CA}}$ (DSD) in the first year of GH treatment. In 
Table 4 Final height in girls with Turner's syndrome treated with growth hormone

\begin{tabular}{|c|c|c|c|c|c|c|c|c|}
\hline \multirow[b]{2}{*}{ Reference } & \multirow[b]{2}{*}{$n$} & \multicolumn{2}{|l|}{ Growth hormone } & \multirow{2}{*}{$\begin{array}{l}\text { Oxandrolone dose } \\
\text { (mg/kg/day) }\end{array}$} & \multicolumn{2}{|l|}{ Ethinyl oestradiol } & \multicolumn{2}{|c|}{ FH gain over (mean) } \\
\hline & & Age start (years) & Dose (IU/m²/week) & & Age start (years) & Dose (ng/kg/day) & $B P(\mathrm{~cm})$ & (m) $P A H(\mathrm{~cm})$ \\
\hline Massa et al $(1995)^{10}$ & 45 & $\begin{array}{l}<12 \\
>12\end{array}$ & $\begin{array}{l}24 \\
2 \text { years GH: } 24 \\
>2 \text { years } \mathrm{GH}: 36\end{array}$ & & $>12$ & 100 & 4.7 & 2.6 \\
\hline $\begin{array}{l}\text { Van den Broeck et al } \\
(1995)^{7}\end{array}$ & 78 & Mean $11.7-14.6$ & $\sim 21-27$ & & Mean 14.5 & $2-5 \mu \mathrm{g} /$ day & 3.3 & 3.0 \\
\hline $\begin{array}{l}\text { Taback et al } \\
(1996)^{11}\end{array}$ & $\begin{array}{l}17 \\
14\end{array}$ & Median 12.4 & $\begin{array}{l}\sim 29 \\
\text { None }\end{array}$ & & $\begin{array}{l}\text { Median } 13.0 \\
\text { Median } 13.3\end{array}$ & $\begin{array}{l}5-20 \mu \mathrm{g} / \mathrm{day} \\
5-20 \mu \mathrm{g} / \mathrm{day}\end{array}$ & $\begin{array}{l}- \\
-\end{array}$ & $\begin{array}{l}-0.2 \\
-3.3\end{array}$ \\
\hline Nilsson et al $(1996)^{8}$ & $\begin{array}{l}44 \\
6\end{array}$ & Mean 12.2 & $\begin{array}{l}1 \text { year: no GH } \\
>1 \text { year: } \sim 21\end{array}$ & 0.05 & Mean 15.3 & $\begin{array}{l}\text { In } 4 \text { years from } \\
100 \text { to } 400\end{array}$ & - & 7.4 \\
\hline & 7 & & $\begin{array}{l}1 \text { year: no GH } \\
>1 \text { year: } \sim 21\end{array}$ & 0.05 & Mean $\sim 13.3$ & 100 & - & 4.3 \\
\hline & 16 & & $\sim 21$ & 0.05 & Mean $\sim 15.1$ & $\begin{array}{l}\text { In } 4 \text { years from } \\
100 \text { to } 400\end{array}$ & - & 8.5 \\
\hline & 15 & & $\sim 21$ & 0.05 & $\begin{array}{l}\text { Mean } 12.3 \\
\text { Mean BA } 10.7\end{array}$ & 100 & - & 3.0 \\
\hline $\begin{array}{l}\text { Rosenfeld et al } \\
\quad(1992)^{12}\end{array}$ & 30 & 9.3 & $\begin{array}{l}\sim 31.5 \\
\sim 31.5\end{array}$ & $\begin{array}{l}0.0625 \\
\text { None }\end{array}$ & $\mathrm{BA} \geqslant 14$ & - & $\begin{array}{l}- \\
-\end{array}$ & $\begin{array}{r}10.4 \\
5.6\end{array}$ \\
\hline $\begin{array}{l}\text { Haeusler et al } \\
\quad(1996)^{9}\end{array}$ & 20 & $7.3-16.4$ & $\begin{array}{l}0.9-2.5 \text { years: } 12-18 \text {, } \\
\text { thereafter: } 18\end{array}$ & $\begin{array}{l}0.0625 \text { or } 5 \mathrm{mg} \\
\text { testosterone/ } 2 \text { week } \\
\text { intramuscularly }\end{array}$ & Mean BA 13.3 & $\begin{array}{l}\text { In } 18 \text { months } \\
\text { from } 50 \text { to } 200\end{array}$ & - & 9.3 \\
\hline
\end{tabular}

BP, Bayley Pinneau prediction method; (m)PAH, (modified) projected adult height.

conclusion, a "younger bone age" at baseline and a higher increase in $\mathrm{HSDS}_{\mathrm{CA}}$ (DSD) in the first year of $\mathrm{GH}$ treatment predict a higher final height gain after $\mathrm{GH}$ treatment.

Previous publications on the effect of $\mathrm{GH}$ treatment on final height in girls with Turner's syndrome are summarised in table 4 . The only other study in which girls with Turner's syndrome used a GH dose comparable with the dose in our study is described by Massa et al. ${ }^{10}$ The lower final height gain in that study compared with our results can be explained by the lower GH injection frequency and/or total GH dose each week in the first two years of the study. Other studies in which "relatively old" girls were treated with lower $\mathrm{GH}$ doses (without oxandrolone) are quite disappointing. ${ }^{71}$ In the published studies in which girls with Turner's syndrome started GH treatment at a younger age and/or were treated with $\mathrm{GH}$ in combination with oxandrolone, the gain in height was comparable with or better than that of our study. ${ }^{8912}$ The effect of a relatively short period of higher dose $\mathrm{GH}$ treatment on final height gain seems to be comparable with the effect of long term lower $\mathrm{GH}$ dose treatment or $\mathrm{GH}$ combined with oxandrolone treatment. In addition, higher GH doses do not seem to have negative side effects. ${ }^{39} 40$ These promising data support the use of higher $\mathrm{GH}$ doses in girls with Turner's syndrome. However, the higher costs of higher $\mathrm{GH}$ doses compared with the lower costs of oxandrolone should be taken into consideration when the use of higher $\mathrm{GH}$ doses is discussed.

Although oestrogen treatment in girls with Turner's syndrome can result in an acceleration of bone maturation if initiated too early, ${ }^{41}{ }^{42}$ the effect of low dose oestrogen starting within the normal range of age of puberty on final height is not clear. Nilsson et al found a significantly lower final height gain in the girls who started at a mean chronological age of 12.3 years with $100 \mathrm{ng}$ ethinyl oestradiol $/ \mathrm{kg} /$ day compared with the final height gain of the girls who started ethinyl oestradiol at a mean chronological age of at least 15.1 years. However, the difference in final height gain between these groups seems to be caused by a decreased height velocity in the second and subsequent years of the treatment in the "young starting ethinyl oestrodiol group" and not by a significant acceleration of the bone maturation in the first three years of $\mathrm{GH}$ treatment. ${ }^{8}$ Other GH (with or without oxandrolone) studies in which the induction of puberty was delayed until the epiphysial plates were almost closed, ${ }^{79}{ }^{12}$ showed no obvious better final height gain than that of our study, in which low dose oestrogens were combined with a relatively high GH dose. Despite the low oestrogen dose, apart from one girl who was still prepubertal, all girls had breast development at the end of GH treatment. Sixteen of 19 girls had breast stage 3 or more and six girls had experienced their menarche. We consider it of utmost importance for the psychological well being of the girls to have their pubertal development in conformity with their peers.

\section{Conclusions}

Division of the total daily $\mathrm{GH}$ dose of $6 \mathrm{IU} / \mathrm{m}^{2}$ / day into two thirds in the evening and one third in the morning is not advantageous over the once daily $\mathrm{GH}$ regimen with respect to final height gain. In addition, treatment with a $\mathrm{GH}$ dose of $6 \mathrm{IU} / \mathrm{m}^{2} /$ day in combination with low dose oestrogens can result in a significant increase in adult height in girls with Turner's syndrome, even if they start GH treatment at a relatively late age.

We gratefully acknowledge the support of A van de Wiel and I van Slobbe in performing this study. This study was supported by Novo Nordisk A/S, Denmark. 1 Ranke MB, Pflüger H, Rosendahl W, et al. Turner syndrome:
spontaneous growth in 150 cases and review of the
literature. Eur f Pediatr 1983;141:81-8.
2 Karlberg J, Albertsson-Wikland K, Naeraa RW, Rongen-
Westerlaken C, Wit JM. Reference values for spontaneous
growth in Turner girls and its use in estimating treatment
effects. In: Hibi I, Takano K, eds. Basic and clinical approach
to Turner syndrome. Amsterdam: Elsevier Science Publish-
ers, 1993:83-92.
3 Underwood LE. The social costs of being short: social perceptions and biases. Acta Pediatr Scand 1991;377(suppl):3 8. 
4 Stahnke N, Stubbe P, Attanasio A, Reinhardt D, Partsch CJ, Sippell WG. GH therapy alone or together with oxandrolone in 212 patients with Turner syndrome (TS): the
German experience. In: Hibi I, Takano K, eds. Basic and clinical approach to Turner syndrome. Amsterdam: Elsevier clinical approach to Turner syndrom

5 Chaussain JL, Gendrel C, Job B, Ducret JP. Optimizing of the dose of growth hormone in girls with Turner syndrome. In: Hibi I, Takano K, eds. Basic and clinical approach to Turner syndrome. Amsterdam: Elsevier Science Publishers, 1993:273-8

6 Teunenbroek van A, Muinck Keizer-Schrama de SMPF, Stijnen $\mathrm{T}$, et al. Yearly stepwise increments of the growth hormone dose results in a better growth response after four years in girls with Turner syndrome. $f$ Clin Endocrinol Metab 1996;81:4013-21.

7 Van den Broeck J, Massa GG, Attanasio A, et al. Final height after long-term growth hormone treatment in Turner synafter long-term growth hormone treat

8 Nilsson KO, Albertsson-Wikland K, Alm J, et al. Improved final height in girls with Turner's syndrome treated with final height in girls with Turner's syndrome treated with growth hormone

9 Haeusler G, Schmitt K, Blümel P, Plöchl E, Waldhör T, Frisch H. Growth hormone in combination with anabolic steroids in patients with Turner syndrome: effect on bone maturation and final height. Acta Paediatr 1996;85:140814.

10 Massa G, Otten BJ, Muinck Keizer-Schrama SMPF, et al. Treatment with two growth hormone regimens in girls with Turner syndrome: final height results. Horm Res 1995;43: $144-6$.

11 Taback SP, Collu R, Deal CL, et al. Does growth hormone supplementation affect adult height in Turner's syndrome? Lancet 1996;348:25-7.

12 Rosenfeld RG, Frane J, Attie KM, et al. Six-year results of a randomized, prospective trial of human growth hormone and oxandrolone in Turner syndrome. $\mathcal{F}$ Pediatr 1992;121: 49-55.

13 Rongen-Westerlaken C, Wit JM. Growth hormone therapy in Turner syndrome: the Dutch experience. In: Ranke MB, Rosenfeld R, eds. Turner syndrome: growth promoting therapies. Amsterdam: Elsevier Science Publishers, 1991 225-9.

14 Nienhuis HE, Rongen-Westerlaken C, Wit JM, et al. Results of long-term therapy with growth hormone in two dose regimens in Turner syndrome. Horm Res 1993;39(Suppl 2):31-6.

15 Albertsson-Wikland K, Rosberg S. Analyses of 24-growth hormone profiles in children: relation to growth. $\mathcal{F}$ Clin Endocrinol Metab 1988;67:493-500.

16 Ross JL, Long LM, Loriaux DL, Cutler GBJ. Growth hormone secretory dynamics in Turner syndrome. F Pediatr 1985;106:202-6.

17 Ranke MB, Blum WF, Haug F, et al. Growth hormone, somatomedin levels and growth regulation in Turner's syndrome. Acta Endocrinol 1987;116:305-13.

18 Lanes R, Brito S, Suniaga M, Moncada G, Borges M Growth hormone secretion in pubertal age patients with 2 .

19 Es van A, Massarano AA, Wit JM, et al. 24-Hour growth hormone secretion in Turner syndrome. In: Ranke MB, Rosenfeld R, eds. Turner syndrome: growth promoting therapies. Amsterdam: Elsevier Science Publishers, 1991: 29-33.

20 Wit JM, Massarano AA, Kamp GA, et al. Growth hormone $(\mathrm{GH})$ secretion in Turner girls as determined by time series analysis. Acta Endocrinol 1992;127:7-12.

21 Kamp GA, Kuilboer MM, Wynne HJ, et al. Slow baseline growth and a good response to growth hormone (GH) therapy are related to elevated spontaneous GH pulse frequency in girls with Turner's syndrome. 7 Clin Endocrinol Metab 1993;76:1604-9.

22 Smith PJ, Hindmarsh PC, Brook CGD. Contribution of dose and frequency of administration to the therapeutic dose and frequency of administration to the therapeutic

23 Teunenbroek van A, Muinck Keizer-Schrama de SMPF, Stijnen T, et al. Growth response and levels of growth fac-
tors after two years growth hormone treatment are similar tors after two years growth hormone treatment are similar for a once and twice daily injection regimen in girl
Turner syndrome. Clin Endocrinol 1997;46:451-9.
24 Teunenbroek A, Muinck Keizer-Schrama SMPF, Stijnen T, et al. Effect of growth hormone administration frequency on 24-hour growth hormone profiles and levels of other growth related parameters in girls with Turner's syndrome. Clin Endocrinol 1993;39:77-84.

25 Tanner JM. Growth at adolescence. Oxford: Blackwell Science Ltd, 1962.

26 Tanner JM, Whitehouse RH, Cameron N, Marshall WA, Healy MJR, Goldstein H. Assessment of skeletal maturity and prediction of adult height (TW2-method), 2nd ed. London: Academic Press, 1983

27 Cameron N. The methods of auxological anthropometry. In: Falkner F, Tanner JM, eds. Human growth, 2, postnatal growth. London: Tindall, 1978:59-63.

28 Roede MJ, Wieringen JC. Growth diagrams 1980. Netherlands third nationwide survey. Tidjschrift voor Sociale Gezondheidszorg 1985;63(suppl):1-34.

29 Greulich WW, Pyle SJ. Radiographic atlas of skeletal development of the hand and wrist, 2nd ed. California: Stanford University Press, 1959.

30 Bayley NB, Pinneau SR. Tables for predicting adult height from skeletal age: revised for use with the Greulich-Pyle hand standards. F Pediatr 1952;40:423-41.

31 Lyon AJ, Preece MA, Grant DB. Growth curve for girls with Turner syndrome. Arch Dis Child 1985;60:932-5.

32 Teunenbroek A, Stijnen T, Otten B, et al. A regression method including chronological and bone age for predicting final height in Turner syndrome, with a comparison of existing methods. Acta Paediatr 1996;85:413-20.

33 Lenko HL. Prediction of adult height with various methods in Finnish children. Acta Paediatr Scand 1979;68:85-92.

34 Hokken-Koelega ACS, Hackeng WHL, Stijnen T, Wit JM, Muinck Keizer-Schrama SMPF, Drop SLS. 24-Hour plasma GH profiles, urinary GH excretion and plasma IGF-I and -II levels in prepubertal children with chronic renal insufficiency and severe growth retardation. $\mathcal{F}$ Clin Endocrinol Metab 1990;71:688-95.

35 Blum WF, Ranke MB, Kietzmann K, Gauggel E, Zeisel HJ, Bierich JR. A specific radioimmunoassay for the growth hormone $(\mathrm{GH})$-dependent somatomedin-binding protein: its use for diagnosis of GH deficiency. $\mathcal{F}$ Clin Endocrinol Metab 1990;70:1292-8.

36 Carlsson LMS, Rowland AM, Clark RG, Gesundheit N, Wong WLT. Ligand-mediated immunofunctional assay for quantitation of growth hormone-binding protein in human blood. F Clin Endocrinol Metab 1991;73:1216-23.

37 Kratzsch J, Blum WF, Ventz M, Selisko T, Birkenmeyer G, Keller E. Growth hormone-binding protein-related immunoreactivity in the serum of patients with acromegaly is regulated inversely by growth hormone concentration. Eur f Endocrinol 1995;132:306-12.

38 De Schepper J, Craen M, Massa G, et al. Growth hormone therapy in Turner's syndrome: one versus two daily injections. F Clin Endocrinol Metab 1994;79:489-94

39 Teunenbroek van A, Muinck Keizer-Schrama de SMPF, Stijnen T, Aanstoot HJ, Hoogerbrugge N, Drop SLS. Carbohydrate and lipid metabolism during various growth hormone dosing regimens in girls with Turner syndrome. In: Teunenbroek van A, ed. Growth hormone treatment modalities in girls with Turner syndrome. Rotterdam: Erasmus University, 1996:147-69.

40 Teunenbroek van A, Cromme-Dijkhuis AH, Muinck Keizer-Schrama de SMPF, Stijnen T, Drop SLS. Effect of long term growth hormone treatment in high dosages on left ventricular cardiac dimensions in girls with Turner syndrome. In: Teunenbroek van A, ed. Growth hormone treatment modalities in girls with Turner syndrome. Rotterdam: Erasmus University, 1996:173-87.

41 Massa G, Maes M, Heinrichs C, Vandeweghe M, Craen M, Vanderschueren-Lodeweyckx $M$. Influences of spontaneous or induced puberty on the growth promoting effect of treatment with growth hormone in girls with Turner's syndrome. Clin Endocrinol 1993:38:253-60.

42 Naeraa RW, Kastrup KW, Nielsen J. Treatment in Turner syndrome with a low dose peroral $17 \beta$-estradiol alone, or in combination with growth hormone. In: Hibi I, Takano K, eds. Basic and clinical approach to Turner syndrome. Amsterdam: Elsevier Science Publishers, 1993:209-14 